\title{
Proyeksi Ekspor Beras Nasional Melalui Gerakan Tiga Kali Lipat Ekspor (Gratieks) Pertanian Indonesia
}

\author{
Siti Aminatus Sa'diah¹, Novi Diana Badrut Tamami ${ }^{2 *}$ \\ Program Studi Agribisnis Fakultas Pertanian Universitas Trunojoyo Madura \\ Jl. Raya Telang No 02 Kamal Bangkalan Jawa Timur 69162 \\ *Email: novidiana.agb@gmail.com
}

Naskah diterima 24 Juli 2020, Revisi 15 September 2020, Terbit 29 Oktober 2020

\begin{abstract}
Abstrak
DOI: doi.org/10.21107/pamator.v13i2.8527

Indonesia memiliki neraca perdagangan beras yang selalu negatif, artinya impor beras jauh lebih tinggi dari ekspornya. Merujuk pada strategi dan target Kementerian Pertanian Kabinet Indonesia Maju, pemerintah menggalakan kebijakan Gerakan Tiga Kali Lipat Ekspor (Gratieks) oleh petani dan pengusaha. Tujuan penelitian ini adalah untuk: (1) mengetahui perkembangan produksi, konsumsi, dan impor beras di Indonesia pada tahun 1999-2018, serta (2) mengetahui proyeksi ekspor beras Indonesia pada tahun 2019-2023 dengan metode forecasting Moving Average, Double Exponential Smoothing, dan ARIMA terhadap data ekspor tahun 1999-2018. Hasil peramalan menunjukkan bahwa permodelan terbaik adalah ARIMA ordo tentatif p,d,q 101 dengan MAPE 0,94. Berdasarkan target pemerintah tentang tiga kali lipat ekspor dari tahun 2018, masih terdapat marjin yang harus dicapai untuk memenuhi target dengan asumsi kebijakan yang diterapkan sama dengan yang berlaku sebelumnya.
\end{abstract}

Kata Kunci: Peramalan, beras, ARIMA

\begin{abstract}
Indonesia always has a negative rice trade balance, it's mean that rice import is higher than export. Acording to the strategy and target of the Ministry of Agriculture of the "Indonesia Maju"s Cabinet, the government promoted the policy of the Triple Export Movement (Gratieks) by farmers and entrepreneurs. The purposes of this study are to: (1) find out the development of rice production, consumption and import in Indonesia, and (2) find out the projection of Indonesian rice export in 2019-2023 by forecasting method Moving Average, Double Exponential Smoothing, and ARIMA on export data years 1999-2018. Forecasting results show that the best modeling is ARIMA tentative ordo $p, d, q 101$ with MAPE 0.94. Based on the treble targeting by goverment of export from 2018, there is still a margin that must be achieved to the target, assuming the policies applied are the same as those previously applied.
\end{abstract}

Keywords : Forecasting, rice, ARIMA

\section{PENDAHULUAN}

Indonesia sebagai negara agraris tidak terlepas dari sumbangsih berbagai komoditas yang dapat dikembangkan di Indonesia. Pertanian bagi Indonesia merupakan sektor unggulan yang memegang peran penting dalam pemenuhan kebutuhan dalam negeri, terutama kebutuhan pangan. Hasil survei Badan Pusat Statistik (2018) terkait pertumbuhan ekonomi Triwulan II Tahun 2018 yang menyatakan kontribusi pertanian pada laju pertumbuhan produk domestik bruto (PDB) mencapai $13.63 \%$.

Sektor pertanian didominasi oleh subsektor tanaman bahan makanan memiliki kontribusi besar terhadap perekonomian
(Fortunika et al., 2017). Peran padi sebagai komoditas penyumbang pendapatan negara di Indonesia ditunjukkan dengan tingkat produksi $9.44 \%$ dari keseluruhan total produksi dunia (BPS, 2018). Padi merupakan tanaman pangan yang sangat penting, karena beras masih digunakan sebagai bahan makanan pokok serta komoditas strategis di Indonesia (Djafar et al, 2017). Hal ini dapat dilihat dari indikatornya sebagai bahan pangan pokok utama bagi sebagian besar masyarakat $(90 \%)$, melibatkan lebih atas 14 juta rumah tangga petani, dan menyerap lebih dari $40 \%$ tenaga kerja terhadap total tenaga kerja di Indonesia (Hermawan, 2016). 
Tabel 1. Perkembangan Ketersediaan Beras Dalam Negeri

\begin{tabular}{rccrrrr}
\hline Tahun & $\begin{array}{c}\text { Persediaan } \\
\text { beras domestik } \\
\text { (ton) }\end{array}$ & $\begin{array}{c}\text { Konsumsi } \\
\text { (ton) }\end{array}$ & \multicolumn{1}{c}{$\begin{array}{c}\text { Sisa } \\
\text { (ton) }\end{array}$} & \multicolumn{1}{c}{$\begin{array}{c}\text { Stok akhir } \\
\text { (ton) } \\
\text { (dikurangi } \\
\text { stok bulog) }\end{array}$} & $\begin{array}{c}\text { Ekspor } \\
\text { (ton) }\end{array}$ & $\begin{array}{r}\text { Tidak terserap } \\
\text { (ton) }\end{array}$ \\
\hline 2014 & 42.226 .619 & 32.555 .485 & 9.671 .134 & 8.671 .134 & 2.491 & 8.668 .643 \\
2015 & 44.939 .375 & 30.919 .317 & 14.020 .058 & 13.020 .058 & 1.902 & 13.018 .156 \\
2016 & 47.297 .822 & 32.592 .392 & 14.705 .430 & 13.705 .430 & 2.247 & 13.703 .183 \\
2017 & 48.366 .996 & 31.399 .538 & 16.967 .458 & 15.967 .458 & 4.349 & 15.963 .109 \\
2018 & 33.698 .209 & 31.399 .538 & 2.298 .671 & 1.298 .671 & 3.996 & 1.294 .675 \\
\hline
\end{tabular}

Terhitung hingga tahun 2018, Indonesia memiliki neraca perdagangan beras yang selalu negatif, artinya impor beras lebih tinggi dari ekspornya. Merujuk pada strategi dan target Kementerian Pertanian Kabinet Indonesia Maju, pemerintah menggalakan kebijakan Gerakan Tiga Kali Lipat Ekspor (Gratieks) oleh petani dan pengusaha. Berbagai upaya untuk mencapai percepatan produksi dan kualitas komoditas pertanian telah diusung oleh pemerintah, mulai dari PELITA, Revolusi hijau, hingga saat reformasi yaitu bantuan alsintan, subsidi input pertanian, kartu tani, dan lainnya masih belum dapat menyelesaikan kasus neraca perdagangan beras yang selalu negatif. Berdasarkan uraian di atas, adapun tujuan penelitian ini adalah untuk: (1) mengetahui perkembangan produksi, konsumsi, dan impor beras di Indonesia tahun 1999-2018, serta (2) mengetahui proyeksi ekspor beras Indonesia pada tahun 2019-2023.

Permintaan (demand) adalah sejumlah produk yang akan dibeli oleh konsumen dan konsumen dapat membelinya pada berbagai tingkat kemungkinan harga dalam jangka waktu tertentu dan dengan anggapan hal-hal lain tetap sama atau Cetereis Paribus (Hanafie, 2010). Faktor-faktor yang mempengaruhi permintaan meliputi harga barang itu sendiri, harga barang lain, pendapatan rumah tangga dan pendapatan rata-rata masyarakat, corak distribusi pendapatan dalam masyarakat, cita rasa masyarakat, jumlah penduduk, dan ramalan mengenai keadaan di masa yang akan datang (Sukirno, 2013). Secara teorema, kurva permintaan bergerak dari kiri atas ke kanan bawah, sesuai dengan hukum permintaan yang berbunyi "Semakin tinggi tingkat harga, maka jumlah barang yang diminta akan semakin sedikit, dan sebaliknya".

Penawaran (supply) merupakan sejumlah produk tertentu yang akan dijual kepada konsumen pada berbagai tingkat kemungkinan harga dalam jangka waktu tertentu dan dengan asumsi hal-hal lain tetap sama atau Cetereis Paribus (Hanafie, 2010). Menurut Sukirno (2013), faktor para penjual dalam menawarkan produknya pada berbagai tingkat harga ditentukan oleh harga barang itu sendiri, harga barang lain, biaya produksi, tujuan operasional perusahaan, dan tingkat teknologi yang digunakan. Secara teorema, kurva penawaran bergerak dari kiri bawah ke kanan bawah, sesuai dengan hukum penawaran, semakin tinggi tingkat harga, maka jumlah barang yang ditawarkan akan tinggi pula, sebaliknya, jika tingkat harga semakin rendah, maka jumlah barang yang ditawarkanpun semakin sedikit.

Faktor terpenting yang menentukan ekspor adalah kemampuan dari negara tersebut untuk menghasilkan produk-produk yang dapat bersaing di pasar luar negeri. Ekspor secara langsung mempengaruhi pendapatan nasional. Apabila nilai ekspor neto positif, berarti nilai ekspor lebih besar dari nilai impor dan sebaliknya (Benny, 2013). Proses impor umumnya adalah tindakan memasukan barang atau komoditas dari negara lain ke dalam negeri. Impor barang secara besar umumnya membutuhkan campur tangan dari bea cukai di negara pengirim maupun penerima. Kegiatan impor dilakukan untuk memenuhi kebutuhan penduduk suatu negara. Produk impor merupakan barang-barang yang tidak dapat dihasilkan oleh suatu negara atau yang sudah dapat dihasilkan namun tidak dapat mencukupi kebutuhan domestiknya (Benny, 2013). 


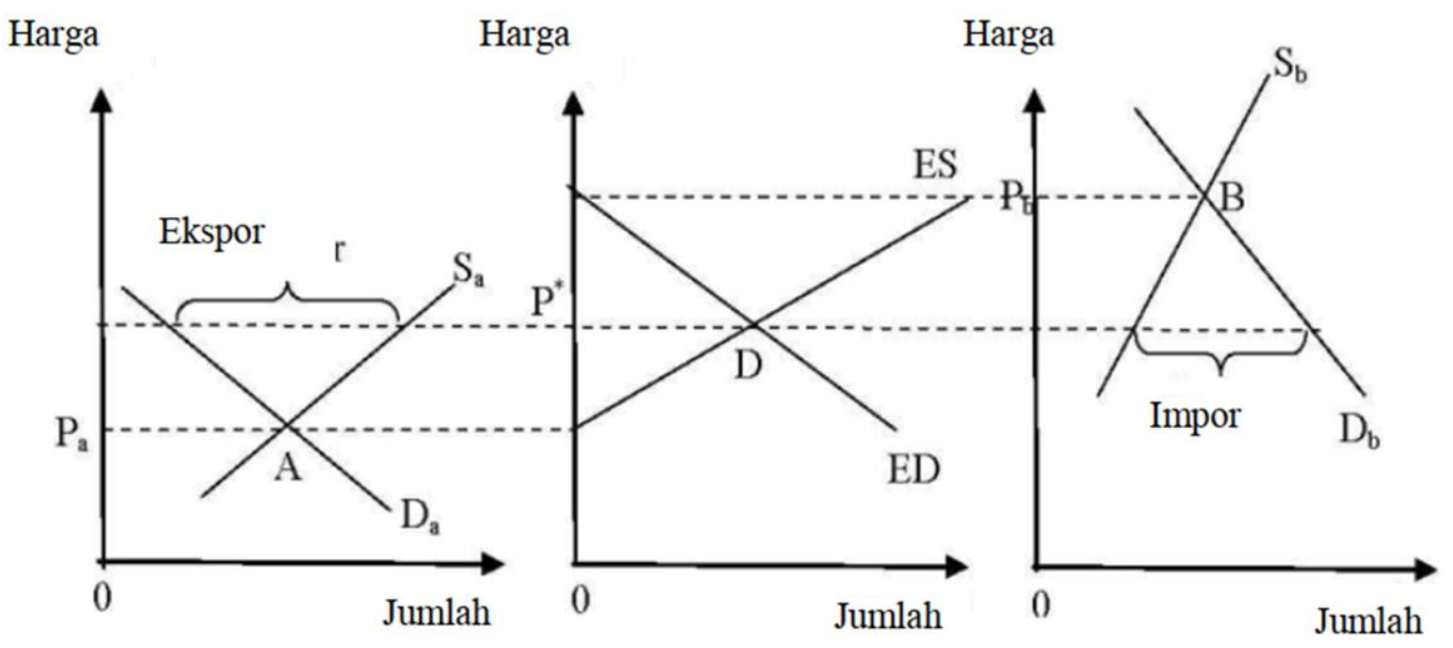

Gambar 1. Kurva perdagangan internasional

Perdagangan internasional terjadi akibat kelebihan penawaran di negara $A$ dan kelebihan permintaan di negara $B$. Pada negara $\mathrm{A}$, harga komoditas sebesar $\mathrm{Pa}$, sedangkan harga komoditas di negara $B$ sebesar $\mathrm{Pb}$, dan cateris paribus. Pada pasar internasional, harga yang dimiliki oleh negara $A$ lebih kecil $\left(P^{\star}\right)$, sehingga negara A akan mengalami kelebihan penawaran (excess supply) di pasar internasional. Pada negara $B$, terjadi harga yang lebih besar dibandingkan harga pada pasar internasional. Hal ini akan menyebabkan kelebihan permintaan (excess demand) di pasar internasional.

Pada keseimbangan di pasar internasional, kelebihan penawaran negara A menjadi penawaran pada pasar internasional ditunjukkan pada kurva ES. Sedangkan kelebihan permintaan negara $B$ menjadi permintaan pada pasar internasional yaitu sebesar ED. Kelebihan penawaran dan permintaan tersebut akan terjadi keseimbangan harga sebesar $\mathrm{P}^{*}$. Peristiwa tersebut akan mengakibatkan negara A melakukan ekspor, dan negara $B$ mengimpor komoditas tertentu dengan harga sebesar $P^{*}$ di pasar internasional. Perdagangan internasional (ekspor-impor) terjadi karena terdapat perbedaan antara harga domestik ( $\mathrm{Pa}$ dan $\mathrm{Pb})$, dan harga internasional $\left(P^{*}\right)$; permintaan (ED), dan penawaran (ES) pada suatu komoditas. Selain itu, nilai tukar mata uang di pasar internasional antar negara secara tidak langsung akan mempengaruhi ekspor dan impor di suatu negara.
Peralaman merupakan kegiatan penerapan model yang telah dikembangkan pada waktu yang akan datang. Peramalan digunakan untuk memperkirakan aktivitas atau kejadian di masa depan dengan menggunakan referensi data di masa lalu untuk meminimumkan pengaruh ketidakpastian. Sedangkan proyeksi menerapkan model yang telah dikembangkan pada waktu yang lalu (Aritonang, 2002). Sebelum model dikembangkan, model akan diuji terlebih dahulu pada kegiatan proyeksi untuk mengetahui apakah model tersebut sudah tepat atau belum.

Metode rata-rata bergerak merupakan metode yang dilakukan dengan menghitung rata-rata suatu nilai runtut waktu dan kemudian menggunakannya untuk meramal pada periode selanjutnya (Aritonang, 2002). Double exponential smoothing merupakan metode yang tepat bagi data yang memiliki pola data musiman dan trend. Koefisien yang digunakan pada motode ini adalah $\alpha$ (alfa). Jika nilai a rendah maka akan menyebabkan jarak lebih lebar dengan trend. Sehingga akan menghasilkan bobot kecil pada permintaan sekarang. Metode ARIMA merupakan analisis yang tidak menggunakan variabel independen, melainkan menggunakan nilai sekarang dan nilai masa lalu dari variabel independen. ARIMA merupakan metode yang mampu digunakan untuk meramalkan pola data trend dan stasioner dan mengatasi deret waktu yang rumit (terdapat variasi dari pola data). 
Penelitian yang dilakukan Indrawati dan Sutijo (2012) menyatakan bahwa beras merupakan salah satu kebutuhan pangan pokok bagi masyarakat Indonesia. Ketersediaan beras yang aman penting untuk dipenuhi oleh suatu negara. Kebutuhan beras berkaitan dengan jumlah konsumsi beras, yang merupakan fungsi dari jumlah penduduk dan konsumsi perkapita. Model terbaik untuk meramalkan produktivitas padi adalah ARIMA ordo tentatif $([3], 0,1)$ dengan deteksi efek data outliers bertipe Additive. Berdasarkan analisis data diketahui bahwa jumlah ketersediaan beras Jawa Timur tahun 20112013 menunjukkan surplus, sehingga dapat dijadikan sebagai pertimbangan bahwa Jawa Timur tidak memerlukan impor beras.

Penelitian Suleman dan Sarpong (2011) menggunakan pendekatan Box-Jenkins untuk memodelkan produksi beras giling. Permodelan terbaik untuk perkiraan produksi beras giling yang dihasilkan adalah ARIMA (2, 1, 0). Meskipun demikian, ramalan sepuluh tahun dengan model ini menunjukkan tren yang meningkat di produksi Indonesia, nilai perkiraan pada 2015 (283.16 ribu ton) tidak cukup baik untuk dibandingkan dengan produksi di Nigeria (2700 ribu ton).

\section{METODOLOGI}

Penelitian ini menggunakan data sekunder yang diperoleh dari Kementerian Pertanian, Badan Pusat Statistik, dan Kementerian Perdagangan RI. Data yang digunakan pada penelitian ini yaitu data ekspor, impor, produksi, dan konsumsi beras Indonesia. Data-data tersebut merupakan data time series tahun 19992018 (dua puluh tahun). Peramalan data beras adalah masalah yang menantang dalam statistik pertanian. Kesulitannya terletak pada permintaan dan penawaran yang dipengaruhi oleh faktor-faktor yang tidak pasti yaitu kebijakan ekonomi, faktor pertanian, kredit langkah-langkah, perdagangan luar negeri, dan lainnya yang berinteraksi secara kompleks. Sejak beberapa dekade terakhir, teknik statistik digunakan untuk mengembangkan model prediksi memperkirakan parameter yang diperlukan (Chauduri, 2013).
Terdapat tiga metode peramalan yang akan peneliti ujikan terhadap data ekspor, diantaranya yaitu: metode rata-rata bergerak (moving average method), metode double exsponential smoothing, dan ARIMA (Box Jenkins). Ketiga metode ini dipilih berdasarkan permodelan terbaik dari penelitian yang telah dilakukan oleh Indrawati dan Sutijo (2012), Andani (2008), Sukiyono dan Rosdiana (2018), Setyawan et al. (2016), Sugiarto, et al. (2015), Kour et al. (2018), Hidayatulloh (2019), serta Suleman dan Sarpong (2011).

\section{Moving Average}

Metode moving average secara matematis ditulis sebagai berikut:

$$
\begin{array}{ll}
M(n)_{t} & =Y_{t+1}=\left(y_{t}+y_{t-1}+y_{t-2}+\ldots+y_{t-n+1}\right) / n \\
a_{t} & =2 M t-M^{\prime} t \\
b_{t} & =\frac{2}{n-1}\left(M_{t}-M_{t}^{\prime}\right) \\
Y_{t+p} & =a_{t}+b_{t p}
\end{array}
$$

Dimana $\mathbf{n}$ merupakan jumlah data aktual ekspor beras, Mt adalah nilai moving average pada periode $t, \mathbf{Y}_{t+p}$ adalah nilai hasil ramalan ekspor beras, $\mathbf{a}_{\mathbf{t}}$ adalah nilai moving average pada periode $t, \mathbf{b}_{\mathbf{t}}$ merupakan nilai trend moving average pada periode $t$, dan $\mathbf{p}$ adalah jumlah periode ekspor beras yang diramalkan

\section{Double Exponential Smoothing}

Penggunaan metode double exponential smoothing dapat digunakan dengan rumus sebagai berikut:

$S_{t}=\alpha X_{t}+(1-\alpha)\left(S_{t}-1+T_{t-1}\right)$

$T_{t}=\beta\left(S_{t}-S_{t-1}\right)+(1-\beta) T_{t-1}$

$Y_{t+p}=S_{t}+p\left(T_{t}\right)$

$S_{t}$ merupakan nilai pemulusan baru data aktual beras beras, $\mathbf{X}_{\mathbf{t}}$ adalah nilai aktual, $\boldsymbol{\alpha}$ adalah koefisien pemulusan atau smoothing $(0<\alpha>1), T_{t}$ merupakan nilai perkiraan trend, $\boldsymbol{\beta}$ yaitu koefisien pemulusan (smoothing) untuk trend $(0<\beta>1)$, $\mathbf{p}$ yaitu jumlah periode ekspor beras yang akan diramalkan, $\mathbf{Y}_{\mathbf{t + p}}$ merupakan nilai ramalan ekspor beras untuk periode mendatang.

\section{Autoregressive Integrated Moving Average (ARIMA)}

Model Autoregressive Integrated Moving Average (ARIMA) merupakan model gabungan dari AR dan MA. Model ini membutuhkan series stasioner sebagai fungsi dari lampaunya dan nilai sekarang 
serta kesalahan lampaunya. Berikut adalah rumusnya:

$$
Y t=b 0+b 1_{y t-1}+\ldots+b p_{y t-p}+e t-a 1_{e t-1}-\ldots-a q_{e t-q}
$$

Yt merupakan nilai series stasioner, bo, b1...bp adalah konstanta dari koefisien model, yt-1...yt-p adalah nilai lampau series yang bersangkutan, dan et...et-q yaitu kesalahan peramalan ekspor beras di masa lalu.

Model analisis peramalan menggunakan metode ARIMA dapat dilakukan dengan langkah: (1) Mengetahui dan menganalisis pola data yang akan digunakan (horizontal, musiman, siklik, atau trend), (2) Melakukan uji stasioneritas dengan uji ACF. Dikatakan tidak stasioner apabila nilai uji ACF < nilai kritis 1\%, 5\%, dan 10\%; (3) Melakukan differencing (pembedaan) untuk menstasionerkan data yang dianggap sebagai nilai d; (4) Menentukan nilai $p$ dan $q$ pada model ARIMA. Nilai $p$ merupakan ordo AR yang memiliki nilai konstanta probabilitas $<5 \%$. Nilai q merupakan ordo MA dengan nilai probabilitas < 5\%; (5) Selanjutnya yaitu mengestimasi model ARIMA, (6) Mencari model ARIMA yang terbaik dengan cara melihat nilai SS terrendah serta $p$ value ordo AR dan MA kurang dari 5\%; (7) Mengukur tingkat kesalahan dengan melihat nilai MSE (Mean Square Error), MAD (Mean Absolute Deviation), MAPE (Mean Absolute Percentage Error), atau MPE. Peramalan dikatakan valid apabila nilai MAPE mendekati nol dan peramalan dengan nilai MAPE terkecil itulah yang akan dipilih sebagai hasil dari peramalan.

MAPE (Mean Absolute Percentage Error) digunakan agar dapat melihat keakuratan suatu peramalan yang membagi nilai tingkat kesalahan peramalan (error) dengan nilai variabel. Nilai MAPE yang terkecil menunjukkan menunjukkan bahwa tingkat kesalahan peramalan semakin kecil sehingga mampu mencerminkan aktualnya. Adapun rumus untuk mengetahui nilai MAPE adalah:

$$
\text { MAPE }=\sum_{i=1} \frac{\left(y i-y^{\prime} i\right) / y i}{n} \times 100 \%
$$

dengan yi merupakan nilai variabel peramalan ekspor beras, y'i adalah nilai ramalan ekspor beras, (yi-y'i) yaitu kesalahan ramalan ekspor beras (error), dan $\mathbf{n}$ merupakan jumlah data yang digunakan untuk peramalan ekspor beras.

\section{HASIL PEMBAHASAN}

Perkembangan Produksi, Konsumsi, dan Impor Beras di Indonesia

Subsektor tanaman bahan makanan menjadi sektor kunci pada sektor pertanian. Subsektor tanaman bahan makanan memiliki nilai kepekaan distribusi, koefisien distribusi, luaran, dan pendapatan tertinggi dibandingkan dengan subsektor lainnya. Hal tersebut menunjukkan bahwa subsektor tanaman bahan makanan dalam meningkatkan luaran dan pendapatan, serta kemampuan mendorong pertumbuhan sektor industri hulu maupun hilirnya adalah yang paling tinggi dibanding dengan subsektor lainnya (Fortunika et al., 2017). Padi dan jagung adalah tanaman yang diproduksi di sebagian besar wilayah pertanian di Indonesia (Urrutia et al., 2017). Produksi beras di Indonesia berasal dari petani padi yang tersebar di berbagai provinsi. Padi yang dihasilkan dari panen akan susut sebesar 5\% akibat kegiatan pengangkutan dan pengeringan, yang selanjutnya disebut dengan gabah siap giling. Beras dihasilkan menjadi sebesar $62.74 \%$ dari hasil total gabah siap giling. Jumlah beras inilah yang disebut dengan persediaan beras domestik atau produksi beras.

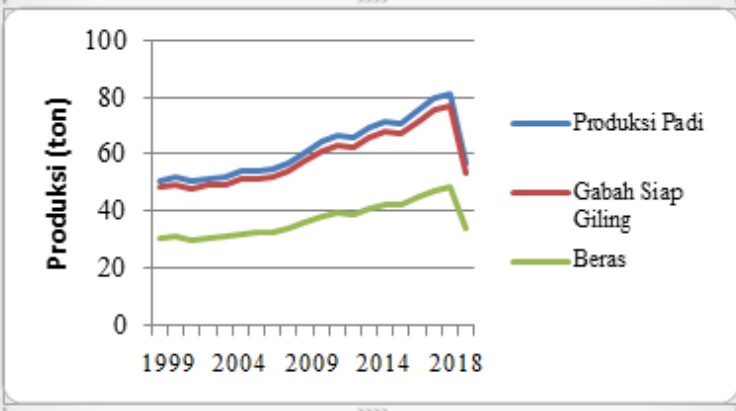

Gambar 2. Perkembangan Produksi Beras Domestik (Juta ton per tahun)

Gambar 2 menunjukkan bahwa produksi beras domestik memiliki tren meningkat. Hal ini menggambarkan bahwa seiring dengan berbagai masalah di bidang pertanian, seperti alih fungsi lahan, keterbatasan alsintan, dan lainnya, komoditas padi masih dapat mempertahankan volume produksinya. Kenaikan volume produksi sangat diperlukan untuk memenuhi kebutuhan masyarakat yang semakin meningkat pula. Tercatat hingga tahun 2017, angka pertumbuhan penduduk di Indonesia mengalami pertumbuhan sebesar $1.04 \%$ 
dari tahun 2013 (Badan Pusat Statistik, 2018). Sejalan dengan penelitian yang dilakukan oleh Rusdiana dan Maesya (2017) yang menyebutkan bahwa pertumbuhan komoditas pangan yang paling tinggi setiap tahun adalah komoditas beras disusul komoditas jagung.

Peningkatan jumlah produksi beras dalam negeri diperlukan untuk memenuhi kebutuhan dalam negeri serta meningkatkan eksistensi beras Indonesia di pasar inernasional. Namun, kendalanya terdapat pada kualitas atau standart yang diinginkan oleh pasar internasional masih belum sesuai dengan beras yang dihasilkan Indonesia. Negara-negara di kawasan Asia menjadi sentra produsen beras dunia, Indonesia bersaing dengan negara-negara penghasil padi dengan berbagai keunggulannya, seperti India dengan luasan panennya yang lebih besar dari Indonesia, Vietnam dengan teknik budidaya yang lebih efisien, Myanmar dengan varietas padi unggulan yang banyak diminati oleh konsumen beras. Oleh karena itu, produksi beras dalam negeri menjadi aspek yang penting untuk dikembangkan untuk meningkatkan eksistensi beras Indonesia.

\section{Konsumsi Beras Nasional}

Jumlah konsumsi beras nasional berasal dari konsumsi dalam rumah tangga maupun luar rumah tangga (industri, jasa, peternakan). Pola makan masyarakat di Indonesia yang mengkonsumsi nasi sebagai makanan sumber karbohidrat utama. Preferensi penduduk Indonesia terhadap beras sangat tinggi, bahkan penduduk yang mempunyai pola pangan pokok bukan beras beralih ke beras karena beras dianggap merupakan sumber kalori yang utama. Disamping itu, beras juga dianggap memiliki citra pangan yang lebih baik secara sosial.

Pertumbuhan ekonomi berpengaruh terhadap kebutuhan pangan sesuai dengan pertambahan jumah penduduk di suatu negara (Rusdiana dan Maesya, 2017). Saat pertumbuhan penduduk meningkat, semakin banyak orang yang akan mencari penerimaan pekerjaan. Orang yang mendapat pekerjaan akan memiliki daya beli yang lebih dalam konsep permintaan, karena diiringi oleh bertambahnya pendapatan yang ia terima. Inilah penyebab teorema permintaan barang akan bergerak.
Sejalan dengan pendapat Sukirno (2013), pertambahan jumlah penduduk akan mempengaruhi tingkat permintaan suatu barang.

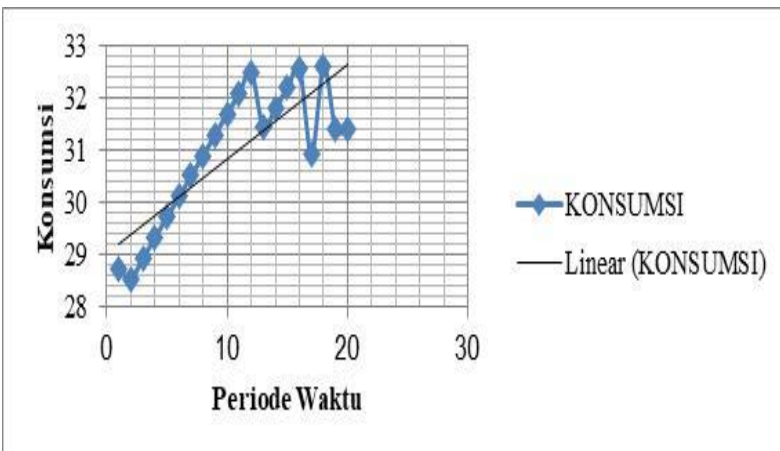

Gambar 3. Perkembangan Konsumsi Beras Nasional Tahun 1999 - 2018 (Juta Ton)

Meskipun terjadi penurunan pada tahun 2013 hingga 2018, namun secara linear, perkembangan konsumsi beras di Indonesia memiliki slope positif. Kurva menggambarkan bahwa dengan semakin bertambahnya volume produksi beras, namun tingkat konsumsi juga turut meningkat. Pada skala rumah tangga, setidaknya setiap orang harus memenuhi kebutuhan karbohidrat dari beras sebesar 330 gram perhari. Pada sektor lain, seperti industri, beras diolah menjadi beragam produk turunan. Masyarakat Indonesia tergolong sebagai masyarakat yang konsumtif, maka dari itu, sifat ini akan meningkatkan tingkat konsumsi beras pula.

\section{Impor Beras}

Beras menjadi bahan pangan pokok yang esensial bagi penduduk di Asia Tenggara, karenanya impor beras masih dilakukan oleh negara-negara Asia Tenggara untuk menjaga stok pangannya meskipun statusnya sebagai negara pengekspor beras (Hermawan, 2013). Swasembada pangan atau lebih luas kedaulatan pangan telah tercapai pada tahun 2016 dengan surplus sebesar 10\%. Pemerintah Indonesia mengimpor beras untuk mengisi stok beras nasional, khususnya untuk rastra dan untuk mendukung efektifitas kebijakan stabilisasi harga (Hermawan, 2016). Namun, dampak dari impor akan mempengaruhi stabilisasi harga di pasar domestik (Kusumah, 2019).

Seiring dengan peningkatan volume produksi beras dalam negeri, hal ini menyebabkan tingkat impor tiap tahunnya berubah. Perubahan tingkat impor 
mempengaruhi kurva permintaan impor beras, yaitu bergerak dari kiri atas ke kanan bawah. Pergerakan kurva seperti ini dapat diartikan sebagai permintaan beras dari luar negeri mengalami penurunan. Stok beras yang tersedia di dalam negeri akan diprioritaskan untuk dihabiskan terlebih dulu dibandingkan dengan harus mengambil langkah impor beras. Selain itu, menurut Setyawan dan Sugiarti (2016) menyatakan bahwa depresiasi kurs dollar menyebabkan nilai rupiah juga melemah, sehingga menyebabkan ekspor meningkat dan impor menurun. Hal ini karena setiap unit dollar yang diperoleh dari kegiatan ekspor akan memperoleh rupiah yang lebih banyak.

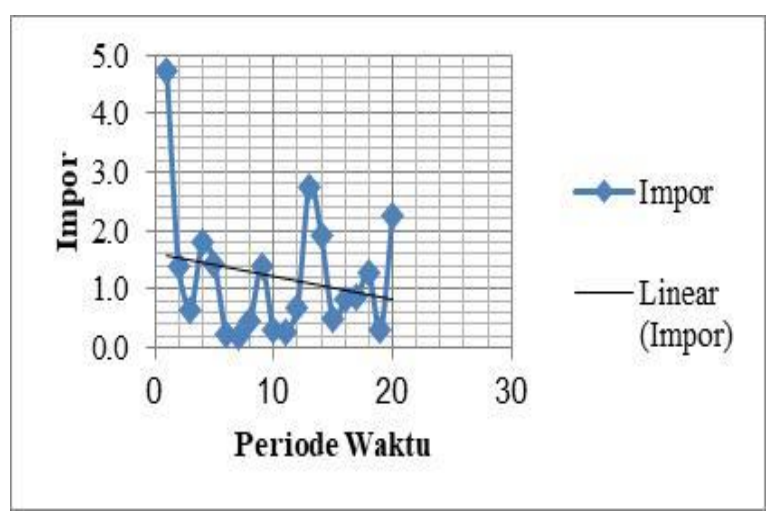

Gambar 4. Perkembangan Impor Beras Di Indonesia (Juta Ton)

Terjadi penurunan impor beras yang drastis dari tahun 1999-2000. Penurunan ini terjadi diakibatkan oleh krisis moneter yang dialami sejak akhir tahun 1997, yang menyebabkan nilai tukar rupiah terhadap dollar mengalami depresiasi. Depresiasi nilai tukar rupiah membuat harga komoditas impor menjadi lebih mahal, maka Indonesia mengurangi jumlah impor. Hal ini menjelaskan bahwa perekonomian suatu negara akan mempengaruhi permintaan suatu produk/ komoditas, sejalan dengan pendapat Sukirno (2013).

Thailand dan Vietnam menjadi negaranegara pengekspor utama beras di wilayah Asia Tenggara, sedangkan Indonesia, Malaysia, dan Filipina sebagai negaranegara pengimpor utama beras di wilayah Asia Tenggara. Pemerintah Indonesia berusaha mencari sumber ketersediaan beras sebesar 3,2 juta ton untuk memenuhi kebutuhan stok 2 juta ton setiap tahun. Hal ini dilakukan untuk melanjutkan intervensi pasar dan program beras miskin (Hermawan, 2013).
Penelitian yang dilakukan oleh Hermawan pada tahun 2013 menunjukkan di wilayah Indonesia pada umumnya belum memiliki pola konsumsi pangan yang beragam dan bergizi seimbang. Konsumsi pangan penduduk masih didominasi oleh sumber karbohidrat beras. Konsumsi di beberapa sentra produksi pangan cenderung memiliki kualitas konsumsi pangan yang rendah, seperti Provinsi Jawa Barat, Jawa Tengah, Jawa Timur, Sumatera Selatan, dan Nusa Tenggara Barat. Hal ini menggambarkan bahwa ketersediaan pangan yang memadai pada suatu wilayah belum menjamin konsumsi pangannya yang berkualitas, karena pola konsumsi pangan erat kaitannya dengan pengetahuan gizi, preferensi, pola perilaku, dan budaya makan penduduk.

\section{Proyeksi Ekspor Beras Indonesia pada Tahun 2019-2023}

Gratieks merupakan kebijakan pemerintah dalam upaya meningkatkan daya saing dan produktifitas komoditas pertanian di Indonesia yang didasarkan pada Peraturan Menteri Pertanian No 19 tahun 2019. Menurut Menteri Pertanian, taraf tiga kali lipat merupakan ukuran yang dikatakan layak untuk sebuah negara kaya raya seperti Indonesia. Kebijakan ini akan ditunjang dengan penggunaan Artificial Intelegent (AI) dalam skema hulu-hilir komoditas pertanian. Melalui gerakan tiga kali lipat ekspor, maka akan mendorong petani agar meningkatkan kuantitas dan kualitas produk yang dihasilkan. Jumlah produk pertanian yang tidak terserap oleh pasar ekspor merupakan produk yang tidak memenuhi standar yang diinginkan oleh negara lain. Hal ini menyebabkan neraca perdagangan menjadi negatif.

Perdagangan beras secara internasional berfungsi untuk menjaga ketersediaan beras yang cukup bagi pemenuhan kebutuhan domestik suatu negara. Eksportir dan importir beras utama dunia di antaranya berada di wilayah Asia Tenggara, sehingga perubahan jumlah beras yang diperdagangkan dapat mempengaruhi aliran perdagangan komoditas beras dari Indonesia. 


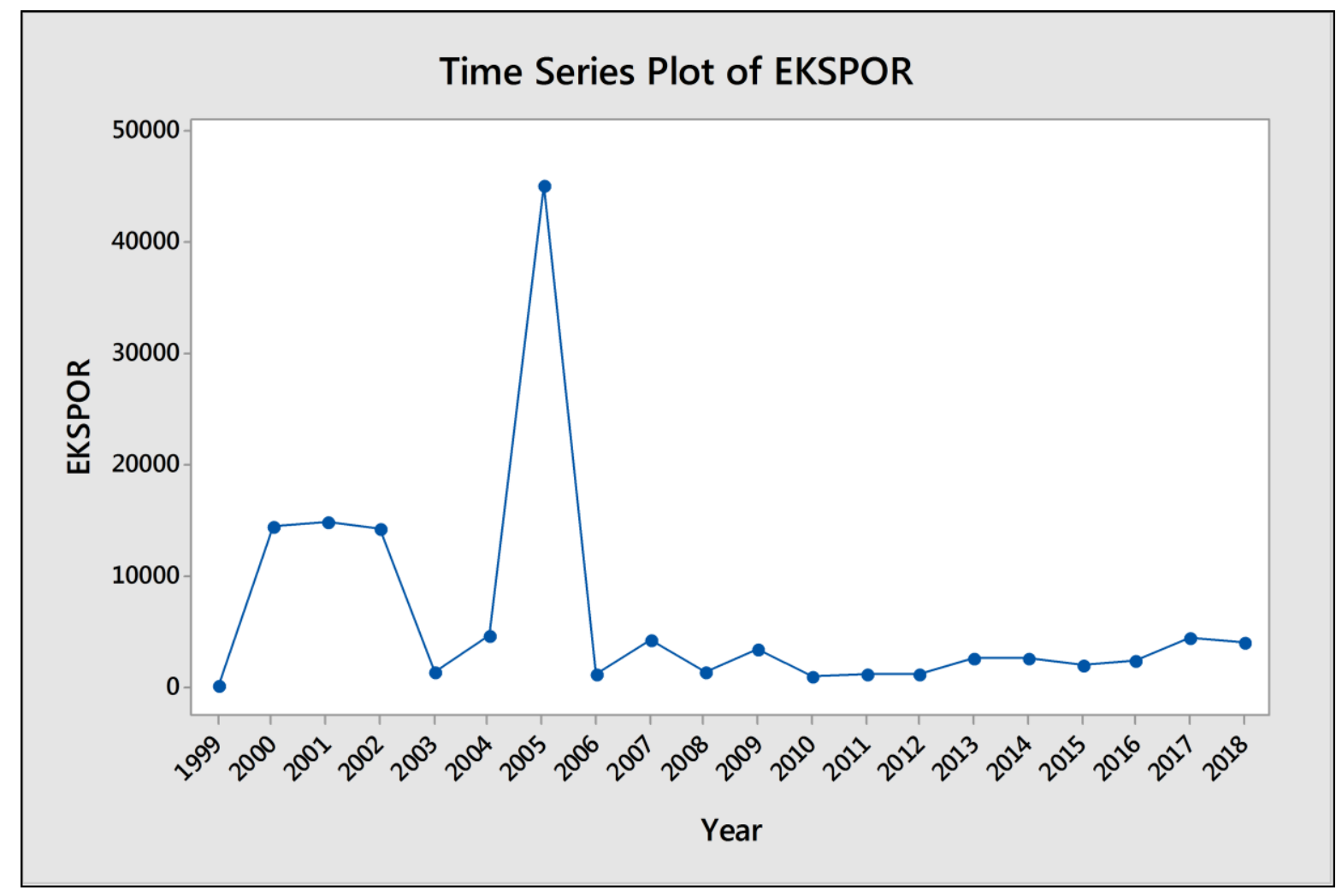

Gambar 5. Pola data ekspor beras tahun 1999-2018 (ton)

Secara time series plot, data ekspor beras di Indonesia memiliki pola yang tidak stasioner. Model peramalan yang akurat untuk suatu data runtun waktu sulit diperoleh jika datanya kompleks (Gunaryati, 2017). Berdasarkan hasil peralaman yang diperoleh melalui metode Moving Average, Double Exponential Smoothing, dan ARIMA, diperoleh hasil peramalan sebagai berikut: Tabel 2. Hasil Peramalan Data Ekspor (Ton)

\begin{tabular}{crrr}
\hline Tahun & MA & \multicolumn{1}{c}{ DES } & \multicolumn{1}{c}{ ARIMA } \\
\hline 2019 & 2997.0 & 175.3 & 5230.3 \\
2020 & 2997.0 & -318.7 & 5233.2 \\
2021 & 2997.0 & -812.7 & 5236.1 \\
2022 & 2997.0 & -1306.8 & 5239.0 \\
2023 & 2997.0 & -1800.0 & 5242.0 \\
\hline MAPE & 289 & 559 & 0.940 \\
\hline
\end{tabular}

Berdasarkan hasil pramalan, selanjutnya menentukan model yang paling sesuai. Menurut Makridakis et al. (1999), untuk menentukan model yang paling sesuai adalah dengan membandingkan nilai MAPE, apabila nilai MAPE semakin kecil, maka model tersebutlah yang paling sesuai atau mendekati nilai aktual. Model terbaik dengan MAPE terpilih juga digunakan untuk menduga kasus pada penelitian Nugraha
(2017), Mustabsyiroh et al. (2014), dan Ramadania (2018). Dari tabel dapat dilihat bahwa hasil peramalan ARIMA memiliki nilai MAPE yang paling rendah, yaitu sebesar 0.940. Maka pada penelitian ini akan memproyeksikan tingkat ekspor beras dengan metode ARIMA dengan ordo tentatif p,d,q 101.

Pada tahun 2023, masih terdapat selisih antara target yang diinginkan pemerintah dengan proyeksi volume ekspor di masa mendatang. Hal ini terjadi dengan asumsi bahwa kebijakan dan stategi yang diberlakukan masih sama dengan yang diterapkan di tahun 2018. Maka, apabila pemerintah menargetkan Indonesia dapat mencapai Gratieks di akhir periode pembangunan, pemerintah disarankan agar memperbarui kebijakan dan strategi pada sektor pertanian, terutama untuk meningkatkan produksi dan daya saing produk pertanian domestik.

Tabel 3. Prediksi Marjin Target Ekspor Dengan Proyeksi Lima Tahun Mendatang

\begin{tabular}{llcc}
\hline Tahun & $\begin{array}{l}\text { Target } \\
\text { (Ton) }\end{array}$ & $\begin{array}{c}\text { Proyeksi } \\
\text { (Ton) }\end{array}$ & $\begin{array}{c}\text { Marjin } \\
\text { (Ton) }\end{array}$ \\
\hline 2019 & 11988 & 5230 & 6758
\end{tabular}




\begin{tabular}{llcc}
\hline Tahun & $\begin{array}{c}\text { Target } \\
\text { (Ton) }\end{array}$ & $\begin{array}{c}\text { Proyeksi } \\
\text { (Ton) }\end{array}$ & $\begin{array}{c}\text { Marjin } \\
\text { (Ton) }\end{array}$ \\
\hline 2020 & 11988 & 5233 & 6755 \\
2021 & 11988 & 5236 & 6752 \\
2022 & 11988 & 5239 & 6749 \\
2023 & 11988 & 5242 & 6746 \\
\hline
\end{tabular}

Salah satu program unggulan yang pernah dijalankan pada komoditas pangan yaitu program Go Organic. Program Go Organic adalah program yang diusung pemerintah bertujuan untuk meningkatkan ketahanan pangan dan kesejahteraan masyarakat, dengan visi mewujudkan Indonesia sebagai salah satu produsen pangan organik terbesar di dunia pernah digalakan pada tahun 2010 (Sulistyana et al., 2014). Selain itu, menurut Siswanto et al. (2018), simulasi kebijakan peningkatan subsidi pupuk memiliki dampak yang hampir sama dengan simulasi kebijakan peningkatan kredit pertanian, karena kedua simulasi tersebut merupakan kebijakan subsidi input yang dapat dijadikan insentif bagi petani untuk meningkatkan produksi. Peningkatan subsidi pupuk dijadikan petani untuk meningkatkan jumlah produksi padi, lalu diikuti dengan peningkatan produksi beras dengan besaran yang sama.

Beberapa alternatif dapat dijalankan berdasarkan beberapa hasil penelitian, meliputi: (1) upaya-upaya untuk meningkatkan produktivitas padi di masingmasing negara melalui introduksi jenis padi varietas unggul dan teknik budidaya, mendorong investasi untuk meningkatkan infrastruktur dan logistisk perberasan mulai dari subsistem hulu hingga hilir sehingga tingkat produktivitas padi dan industri hilir padi dapat berkembang (Hermawan, 2013), (2) mengupayakan secara sistematis dan struktural untuk meningkatkan daya saing produk pertanian Indonesia terutama produktivitas dan kualitas, (3) mempersiapkan dengan matang rencana atau tahapan agar produk pertanian domestik dapat menjadi produk yang kompetitif di masa mendatang, (4) menambahkan capacity building dalam beberapa aspek (Laksani dan Putri, 2015), karena kebijakan tunggal tidak mampu meningkatkan kesejahteraan produsen maupun konsumen (Siswanto, 2018).

\section{KESIMPULAN}

Perkembangan produksi dan konsumsi beras di Indonesia memiliki tren positif. Ketersediaan beras domestik dapat mencukupi kebutuhan dalam negeri, hal ini menyebabkan kurva permintaan impor beras meniliki slope yang negatif. Meskipun demikian, masih terdapat stok beras yang tidak terserap oleh pasar, baik domestik maupun internasional. Hasil peramalan terhadap tingkat ekspor dengan model terbaik yaitu ARIMA ordo tentatif $p, d, q 101$ menunjukkan tingkat ekspor beras lima tahun mendatang belum dapat memenuhi target tiga kali lipat yang diinginkan, terhitung sebesar 11988 ton yang merupakan tiga kali lipat dari tahun 2018 yang sebesar 3996 ton. Maka, pemerintah disarankan agar menerapkan kebijakan terbaru untuk memenuhi marjin proyeksi ekspor dengan target yang masih di atas 6000 ton. Kebijakan yang mengarah pada peningkatan produksi serta daya saing beras Indonesia di pasar internasional.

\section{DAFTAR PUSTAKA}

Andani, A. 2008. Analisis Prakiraan Produksi dan Konsumsi Beras Indonesia. Jurnal AGRISEP Vol. 8 No. 1.

Aritonang, L. 2002. Peramalan Bisnis. Jakarta: Ghalia Indonesia.

Badan Pusat Statistik. 2018. Ringkasan Eksekutif Luas Panen dan Produksi Beras di Indonesia 2018. Jakarta: BPS RI.

Benny, J. 2013. Ekspor dan Impor Pengaruhnya terhadap Posisi Cadangan Devisa di Indonesia. Jurnal EMBA Vol. 1 No 4.

Chaudhuri, A. 2013. Forecasting Rice Production in West Bengal State in India: Statistical vs. Computational Intelligence Techniques. International Journal of Agricultural and Environmental Information Systems Vol. 4 (4).

Djafar, et al. 2017. Peramalan Jumlah Produksi Padi di Sulawesi Tenggara Menggunakan Metode Fuzzy Time Series. Jurnal semanTIK. Vol.3 (2).

Fortunika, S.O. 2017. Kontribusi Sektor Pertanian terhadap Perekonomian 
Kabupaten Banjarnegara. Jurnal Agraris Vol. 3 (2).

Gunaryati, A. 2017. Analisis dan Model Peramalan Data Ekspor Impor dengan Metode Gabungan Arima -Neural Network. Jurnal String Vol. 2 (1).

Hanafie, R. 2010. Pengantar Ekonomi Pertanian. CV Andi Offset. Yogyakarta.

Hidayatulloh, A. 2019. Proyeksi Produksi dan Konsumsi Daging Sapi Nasional dalam Rangka Swasembada Pangan. Skripsi. Program Studi Agribisnis Fakultas Pertanian Universitas Trunjoyo Madura.

Hermawan, I. 2013. Analisis Perdagangan Beras dan Ketahanan Pangan di NegaraNegara Asia Tenggara. Jurnal Politica Vol. 4 (2).

---------------. $2016 . \quad K e b i j a k a n$ Perberasan Indonesia dan Solidaritas Pangan Asean. Jurnal Politica Vol. 7 No. 1.

Indrawati, F.B.N \& Sutijo, B. 2012. Pemodelan Jumlah Ketersediaan Beras dengan Pendekatan Fungsi Transfer. Jurnal Sains dan Seni ITS. Vol.1 (1).

Kusumah, P.F. 2019. Ekonomi Politik dalam Kebijakan Impor Beras: Membaca Arah Kebijakan Pemerintah 2014-2019 . Jurnal Politika. Vol.10 (2).

Laksani, D \& Putri, E.R. 2015. Tarif Bea Masuk Optimal bagi Produk Pertanian Indonesia. Jurnal Agriekonomika. Vol. 4 (2).

Makridakis, et al. 1999. Metode dan Aplikasi Peramalan Jilid 1. Jakarta: Binarupa Aksara.

Mustabsyiroh, et al. 2014. Peramalan Tingkat Produktivitas Daerah Potensial Pangan di Kudus. Universitas Muria Kudus: Prosiding SNATIF Ke-1.

Nugraha, D. 2017. Ketersediaan Jagung Berdasarkan Peramalan Produksi dan Produktivitasnya di Tengah Persaingan Penggunaan Lahan di Indonesia. Pusat Penelitian dan Pengembangan Tanaman Pangan: Prosiding Seminar Nasional Agroinovasi Spesifik Lokasi Untuk Ketahanan Pangan Pada Era Masyarakat
Ekonomi ASEAN. Universitas Muria Kudus: Prosiding SNATIF $\mathrm{Ke}-1$ ISBN: 978-602-1180-04-4.

Pusat Data dan Sistem Informasi Pertanian . 2016. Outlook Komoditas Pertanian Padi. Kementerian Pertanian Republik Indonesia.

Ramadania, R. 2018. Peramalan Harga Beras Bulanan di Tingkat Penggilingan dengan Metode Weighted Moving Average. Buletin IImiah Math. Stat. dan Terapannya (Bimaster). Volume 7 (4). $329-334$ pp.

Rusdiana, S \& Maesya, A. 2017. Pertumbuhan Ekonomi dan Kebutuhan Pangan di Indonesia. Jurnal Agriekonomika. Vol 6 (1).

Sediaoetama, D A. 1989. IImu Gizi II. Jakarta: Dian Rakyat.

Salvatore, D. 1990. Ekonomi Internasional Jilid 1. Jakarta: Erlangga.

Setyawan, E. 2016. Analisis Peramalan (Forecasting) Produksi Karet (Hevea Brasiliensis) di PT Perkebunan Nusantara IX Kebun Sukamangli Kabupaten Kendal. Jurnal Mediagro. Vol. 12 (2).

Setyawan, E \& Sugiarti, T. 2016. Daya Saing dan Faktor Penentu Ekspor Kopi Indonesia ke Malaysia Dalam Skema Cept-Afta. Jurnal Agriekonomika. Vol 5 (2).

Siswanto, et al. 2018. Dampak Kebijakan Perberasan pada Pasar Beras dan Kesejahteraan Produsen dan Konsumen Beras di Indonesia. Jurnal IImu Pertanian Indonesia. Vol 23 (2).

Sugiarto, S, et al. (2015). Peramalan Stok Beras Bulog Pekanbaru dengan Menggunakan Model Pemulusan Winter dan Arma $(p, q)$ (Forecasting Rice Stocks Bulog Pekanbaru Using Winter Smoothing And Arma (p,q) Model). Universitas Tanjungpura Pontianak: Prosiding Semirata 2015 bidang MIPA BKS-PTN Barat HIm 419 - 429.

Suhardjo, et al. 1985. Pangan, Gizi, dan Pertanian. Jakarta: UI Press Salemba. 
Sukirno, S. 2013. Mikroekonomi Teori Pengantar. Jakarta: PT RajaGrafindo Persada.

Sukiyono, K \& Rosdiana. 2018. Pendugaan Model Peramalan Harga Beras pada Tingkat Grosir. Jurnal AGRISEP Vol. 17 (1). $23-30$ pp.

Sulistyana, P. 2014. Konsumsi Beras Organik pada Tingkat Rumah Tangga di Kota Yogyakarta. Jurnal Agro Ekonomi. Vol. 24 (1).
Suleman, N \& Sarpong, S. 2011. Forecasting Milled Rice Production in GhanaUsing Box-Jenkins Approach. International Journal of Agricultural Management \& Development (IJAMAD) Vol. 2 (2).

Urrutia, et al. 2017. Forecasting the Quarterly Production of Rice and Corn in the Philippines: A Time Series Analysis. Journal of Physics: Conf. Series 820. 